\title{
TRANSITION PROGRAM INTO COMPULSORY EDUCATION WITH EMPHASIS ON THE ENHANCEMENT OF INTER-PERSONAL RELATIONSHIPS THROUGH THE IMPLEMENTATION OF APPROPRIATE DEVELOPMENTAL PRACTICES DURING EARLY CHILDHOOD
}

\author{
Maria Sakellariou, \\ Rodokleia Anagnostopoulou ${ }^{i}$ \\ Department of Early Childhood Education, \\ University of Ioannina, \\ Greece
}

\begin{abstract}
:
The success of transition programs into compulsory education by implementing developmentally appropriate practices, the relationship that takes place between the child and the Instructor, play as well as the child's interaction with their peers all comprise significant components of a well-tempered transition. In the context of the current research that was conducted during the 2015-2016 school year, the views of 217 Greek Nursery School Teachers and 194 Kindergarten Educators, all from the wider Epirus Region, were examined on the practices they implement with aims at enhancing inter-personal relationships among children of early age, in order for their experience regarding preschool education and learning centers to be a pleasant one, while the process of transition from one context to the other, to be effective. The research shows that Greek Early Childhood Instructors is of uttermost importance that they possess knowledge on their training expertise along with the emotional facet of the overall transition procedure. It is, furthermore, essential that they should enforce children's active participation into a transition program to compulsory education and assist them on obtaining fundamental social skills on the basic direction of a smooth transition into compulsory education.
\end{abstract}

Keywords: transition, nursery school teachers, kindergarten educators, transition practices, children's inter-personal relationships

i Correspondence: email rodoklia@yahoo.gr 


\section{Introduction}

The key-holders of the transition process on the rights of expressing and influence in their own lives, are children themselves (The UN International Convention of children's rights, 1989), since they are in position of shaping their personal views and verbally expressing their thoughts and emotions (Michalopoulou, 2007). Children's role is hence the most significant one. Even if the child is prepared for the new beginning, transition from the safety and stability of domestic environment into a more intricate context, that of the Nursery School, still marks an important change into their lives (Garrett, 2001; Kagan \& Neuman, 1998), yet being an experience of either exciting or stressful nature (Griebel \& Niesel, 2002). It is about, in fact, the first large-scale detachment from family, which every child experience in their personal, unique manner.

During transition, child's micro-system undergoes a series of alterations (Sidiropoulou, Dimitriadi \& Ralli, 2011). Therefore child, with their admittance into preschool training and education centers, directly confronts challenges, accomplishments, failures and awkwardness (American Academy of Child and Adolescent Psychiatry, 2002). They are due facing an unprecedented, unknown situation, detach form their familiar faces, correspond to a new set of anticipations, enact new roles, interact with peers and adults (Fabian, 2000; Lenga \& Ogden, 2000; Margetts, 1999; Margetts, 2002; Rimm-Kaufman \& Pianta, 2000; Thyssen, 1997). The child furthermore realizes that they actually lose their feeling of uniqueness which so abundantly enjoyed within the domestic environment and that they now shall have to become a part of a group of other children with whom they shall be transacting and developing friendships.

The child needs time to adapt to the new environment's demands (Fowler, 1982; Hains, Fowler \& Chandler, 1988; Repetto \& Correa, 1996) as well as process the stress emanating from detachment. Time needed for child to withstand the above changes and come to terms with them, varies, on each child's case. It could last from a couple of hours to several weeks or even months, on certain cases. After the first two weeks, children usually experience contradictory emotions. On one hand, they seem to be glad about going to school and meeting their peers, they feel sad of parting from their parents on the other (detachment stress) (Griebel \& Niesel, 2002; Margetts, 2006). According to The Early Years Learning Framework for Australia (2009), basic factors that can ascertain a successful transition for children are:

- The implementation of transition programs which are founded on previous and current experiences of children. The assurance of children's active participation into their preparation as well as the collaboration with their family.

- The provision of assistance on children so that they fully comprehend all transitions, routines as well as they are able to negotiate on the changes and become more comfortable with their transitional process into preschool environment.

- The cooperation of child with the educational and special services' personnel. 


\section{Child's role as a "support friend" into the transition process}

According to Howes (1988) children who have at least one friend within the peers group of the nursery school, exhibit less adaptation problems. Furthermore, Margetts as well as Dockett and Perry, on their research conducted at the same year, have pointed out that those children possess more developed social skills and manifest a better academic achievement. Backing of a child by their friend, siblings or an older child (Yeboah, 2002), as they are entering their new environment, infuses joy upon them and increases their urge to explore on the settings, deal with new challenges, evolve their autonomy in comparison to a child who does not have any familiar faces standing by their side (Bernd \& Perry, 1986; Bulkeley \& Fabian, 2006; Einarsdóttir, 2002; Fabian, 2000; Griebel \& Niesel, 1999; Ladd \& Price, 1987; Ladd, 1990; Ladd, 2009; Peters, 2000; Schwarz, 1972; Margetts, 2002; O'Hara, 2000). Within hard times, a friend acts as a social role model and comprises a supporting frame, a source of security and continuity (Bronfenbrenner, 1986) that allows child to incorporate within the groups of peers which had been formed the year before, thus not feeling secluded within the preschool class (Vairinou, 2008).

Consequently, peer interaction and child's ability of making friends and becoming a part of the team, indeed constitutes a great challenge (Pollard, 1996) as well as a vital source of support when the child is detached from their family settings (Brock, Dodds, Jarvis, \& Olusoga, 2016; Van Gennep, 1960). Dockett and Perry (2001) have reported that the existence of friends defines the image a child forms towards school. In particular, children consider their school to be "sobering" when no one is their friend. They simultaneously emphasize on the importance of friendship and the development of new amicable relationships inside school, as this offers them the opportunity to play with other children.

Creating a plentiful learning environment which provides chances of involvement into all play categories (symbolic, structural, dramatic, imaginary, kinetic, creational) can contribute into development and promote a pro-learning attitude such as curiosity, fantasy, creativity, resourcefulness, persistence and the drive for experimentation (Michalopoulou \& Grantza, 2014). Through play the child acquires knowledge, skills and abilities, develops successful strategies, learns how to express their emotions, come up with effective solutions to their problems, elevate their self-esteem and reduce their stress (Pantazis, 2004). Child's capability of actively taking part into peer groups, show respect over playing, collaborate and share toys are some of the basic social skills that can function as a transition tool, helpful to child's experiencing of the new situation as well as verbalizing this experience (Pantazis, 1999).

\section{Transition support programs via developmentally appropriate practices}

Every transition concerning children is a critical one and additional backing is necessary, through designing and implementing realistic transition curricula which are adaptable towards the children's group dynamics, the family's needs as well as those of the broader 
community. Determinative is the role of collaborative groups along with that of the coordinator's for accomplishing an effective designing, harmonization and implementation of appropriate transition educational practices prior to, during and after child's admittance into preschool learning environments.

A variety of programs on supporting family and child from birth to the age of six are globally implemented, utilizing this way a wide spectrum of "promising and hopeful" transition practices. Practices that emphasize on the active participation of family, constructive interaction among the educators of both preschool ranks, cooperation with the community, enhancement of inter-personal relationships among children, on the purpose of bridging the chasm between institutions but also of safeguarding continuity and successful transition. A prerequisite for all the above is infusing awareness on the educational policy in order for gaps to be located, the current educational policy to be itself reviewed, and substantial changes regarding early childhood education to be actualized.

Nursery school teachers on their attempt to facilitate children's transition into Kindergarten either on a personal or on a collective level, adopt the following basic support strategies:

\section{a. Assurance of continuity}

Do you debate with children about their admission into Kindergarten, do you discover the way in which they handle changes during their schooling into Nursery and do you attempt to safeguard a well-tempered continuity with regards to procedures and learning issues through developmentally appropriate programs (Bredekamp, 1987; Patton \& Wang, 2012; Pianta, Rimm-Kaufman, \& Cox, 1999; Piotrkowski, Botsko, \& Matthews, 2000). Do you assist children on acquaint themselves with the school regulations, deem other children as equal team members, respect them and feel secure when living together with their peers in class (Dockett \& Perry, 2003; Fabian, 2000). Furthermore, space organizing and formation of proper preschool conditions shall diminish any adaptation difficulties along with problems on preschoolers and shall assure their well-tempered adaptation (Germanos, 2002, 2004; Rentzou \& Sakellariou, 2014; Barblett, Barratt-Pugh, Kilgallon, \& Maloney, 2011; Bredekamp, 1987). It is crucial that the designing of learning settings resembles that of the domestic one no less to the child's universe of anticipations and fantasies (Pantazis, 2003), provide coziness and comfort (Ntoliopoulou, 2006). It is also important that similarities between the two preschool contexts are formed, so that children shall be able to recognize activities and gain the ability of involving themselves with more complicate ones, as well as feel ready to confront the challenges ahead (Broström, 2005).

\section{b. Exchange of reconnaissance visits between the Nursery School Teachers and pupils and those of the Kindergarten}

Visiting, in the company of the Nursery children to the Kindergarten facility at spring, regardless whether they shall be schooled or not into the specific context (Boham-Baker 
\& Little, 2004; Bogard \& Takanishi, 2005; Cappelloni, 2011; Early, Pianta, Taylor, \& Cox, 2001; La Paro, Kraft-Sayre, \& Pianta, 2003; Lo-Casale Crouch, Mashburn, Downer, \& Pianta, 2008; Patton \& Wang, 2012; Rimm-Kaufman \& Pianta, 1999; Rous, Hallam, McCormick, \& Cox, 2010) allows them familiarize themselves with the new whereabouts, collaborate, play, creatively occupy themselves, pinpoint similarities but also differences between the Nursery School and the Kindergarten, as well as to gain knowledge of the Educators' anticipations. Nursery School children are also provided with the opportunity to make new friends and acquire new preschool experiences, while, at the same time they are under the security of their own familiar friends and their Instructor's company (Margetts, 1999). After the visit to the Kindergarten is finished, the Nursery School Teacher reads children a fairy tale about transition, so that the excursion at their upcoming educational context is linked with the preschool day routine- therefore not comprising an isolate action (Patton \& Wang, 2012). A necessary demand is the preparation of Kindergarten pupils, by their Educator, so that they are friendly and willing to show the prospective new members around the facility and cooperate with them into creating a positive atmosphere (Kitsaras, 1988). Yet more, inviting the Educator and pupils of the nearby Kindergarten to visit the Nursery offers the opportunity to the Educator and the children discuss about Kindergarten and share their experiences (Gill, Winters \& Friedman, 2006 - Lo-Casale Crouch, Mashburn, Downer, \& Pianta, 2008). The Educator, during her visit at the Nursery, could bring back with her an album containing photographs of the Kindergarten personnel, working on their daily acts, all made by the toddlers' hands (Kraft-Sayre \& Pianta, 2000).

\section{c. Participation of Nursery and Kindergarten pupils in common activities-events}

Holding common actions and events between the Nursery School and the Kindergarten (Kitsaras, 1988): This could be either an excursion or merely a walk, a school feast, a charity "bazaar", a pantomime show, sports, dramatization of a fairy tale, theatrical play, or some other sort of project which shall be implemented and presented by the children together (environment, healthcare education et al.).

\section{d. Enhancement of developing friendly relationships among the children}

Encouraging children of 3-5 years to freely form friendships within the Nursery, enhancing positive interaction among a certain division's pupils and those of different ones, all however being due to attend the same Kindergarten, comprises one of the main transition practices that are implemented within Preschool Education and Learning Centers (Kraft-Sayre \& Pianta, 2000), since maintaining good relationships with peers leads to a better psychosocial and preschool acclimatization but also to the acquirement of a positive image towards the new environment (Cappelloni, 2011; Meyer \& BevanBrown, 2000; Peters, 2000). Kindergarten Principals should, therefore, structure groups of children taking on account friendships born within the Nursery or the Kindergarten itself. Especially during the first few days into the new preschool environment children can more effectively cope with new challenges of the Kindergarten when they are 
enjoying their peers' emotional support, whom they see as friends, they hence can hold onto a hand that gives them safety when having to overcome transitional hardships (Bernd \& Perry, 1986; Fabian, 2000; Howes, 1988; Ladd \& Price, 1987; Ladd, 1990; Pellegrini \& Blatchford 2000; Schwarz, 1972).

\section{Material and Methods}

The hereunto study comprises an investigational effort towards contributing into a wider comprehension of Greek Nursery School Teachers (N:217) and Kindergarten Educators (N:194) all working in facilities at the broader Epirus Region, regarding the practices they implement during the transition of children form Nursery to Kindergarten, with aims at the enhancement of inter-personal relationships among preschoolers towards a welltempered adaptation of children into the new educational context. The educationalists' participation was by all senses optional and anonymous. The sampling was random so that it would be deemed as representative of the population under scrutiny (Cohen \& Manion, 1994).

\section{Presentation of the Results}

\subsection{Practices which are used for the enhancement of inter-personal relationships among Nursery and Kindergarten children}

As shown in Table 1, regarding the question "Which of the following practices that can be found into the international literature do you implement for enhancing inter-personal relationships among Nursery and Kindergarten children in order to assure a welltempered transition? Please, evaluate on the practices below, either you do implement them or not" it was established that the vast majority of educationalists (93,1\%) evaluates encouraging children to make new friends as being significant and very significant. Following, over $60 \%$ of the educationalists positively evaluates on the enhancement of developing amicable relationships among pupils of the same division who are due to be enrolled into the same Kindergarten $(65,9 \%)$, participation of both, Nursery and Kindergarten pupils into common activities-events $(64,2 \%)$ and the enhancement of forming friendly relationships among children of different divisions who are to be attending the same Kindergarten (62,9\%). Finally, it is about visits and communication among Nursery and Kindergarten children (49,3\%) along with visits and communication among children of different Nurseries who are to be enrolled into the same kindergarten $(35,8 \%)$. 
Table 1: Quantitative of total results regarding practices used towards the enhancement of inter-personal relationships between Nursery and Kindergarten children

\begin{tabular}{|c|c|c|c|c|c|c|}
\hline Practices & 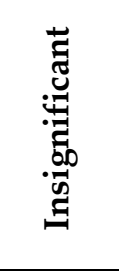 & 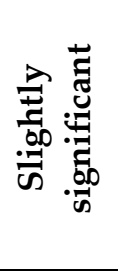 & 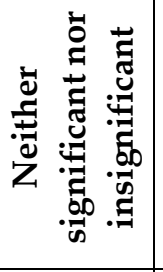 & 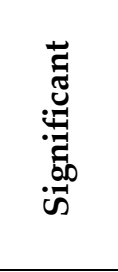 & 胥 & $\begin{array}{c}\text { Kindergarten } \\
\text { Educators-Nursery } \\
\text { School Teachers } \\
\text { Total } \\
\end{array}$ \\
\hline $\begin{array}{l}\text { Visits and communication } \\
\text { between Nursery and } \\
\text { Kindergarten children }\end{array}$ & $\begin{array}{c}35 \\
8.6 \%\end{array}$ & $\begin{array}{c}46 \\
11.3 \%\end{array}$ & $\begin{array}{c}126 \\
30.9 \%\end{array}$ & $\begin{array}{c}140 \\
34.3 \%\end{array}$ & $\begin{array}{c}61 \\
15.0 \%\end{array}$ & \multirow{2}{*}{$\begin{array}{c}408 \\
100 \%\end{array}$} \\
\hline $\begin{array}{l}\text { Visits and communication between } \\
\text { different Nurseries' children who } \\
\text { shall be admitted into the same } \\
\text { Kindergarten }\end{array}$ & $\begin{array}{c}47 \\
11.5 \%\end{array}$ & $\begin{array}{c}53 \\
13.0 \%\end{array}$ & $\begin{array}{c}162 \\
39.7 \%\end{array}$ & $\begin{array}{c}102 \\
25.0 \%\end{array}$ & $\begin{array}{c}44 \\
10.8 \%\end{array}$ & \\
\hline $\begin{array}{l}\text { Enhancement of developing } \\
\text { friendly relationships among the } \\
\text { same division's children who shall } \\
\text { be admitted into the same } \\
\text { Kindergarten }\end{array}$ & $\begin{array}{c}21 \\
5.1 \%\end{array}$ & $\begin{array}{c}22 \\
5.4 \%\end{array}$ & $\begin{array}{c}97 \\
23.7 \%\end{array}$ & $\begin{array}{c}172 \\
42.0 \%\end{array}$ & $\begin{array}{c}98 \\
23.9 \%\end{array}$ & \multirow{2}{*}{$\begin{array}{c}410 \\
100 \%\end{array}$} \\
\hline $\begin{array}{l}\text { Enhancement of developing } \\
\text { friendly relationships among } \\
\text { different divisions' children who } \\
\text { shall be admitted into the same } \\
\text { Kindergarten }\end{array}$ & $\begin{array}{c}25 \\
6.1 \%\end{array}$ & $\begin{array}{c}30 \\
7.3 \%\end{array}$ & $\begin{array}{c}100 \\
24.4 \%\end{array}$ & $\begin{array}{c}173 \\
42.2 \%\end{array}$ & $\begin{array}{c}82 \\
20.0 \%\end{array}$ & \\
\hline $\begin{array}{l}\text { Encouragement of children to } \\
\text { freely create new friendships }\end{array}$ & $\begin{array}{c}3 \\
0.7 \%\end{array}$ & $\begin{array}{c}4 \\
1.0 \%\end{array}$ & $\begin{array}{c}21 \\
5.1 \%\end{array}$ & $\begin{array}{c}167 \\
40.9 \%\end{array}$ & $\begin{array}{c}213 \\
52.2 \%\end{array}$ & \multirow{2}{*}{$\begin{array}{c}408 \\
100 \%\end{array}$} \\
\hline $\begin{array}{l}\text { Participation of Nursery and } \\
\text { Kindergarten children into } \\
\text { common activities-events }\end{array}$ & $\begin{array}{c}23 \\
5.6 \%\end{array}$ & $\begin{array}{c}34 \\
8.3 \%\end{array}$ & $\begin{array}{c}89 \\
21.8 \%\end{array}$ & $\begin{array}{c}164 \\
40.2 \%\end{array}$ & $\begin{array}{c}98 \\
24.0 \%\end{array}$ & \\
\hline
\end{tabular}

\section{a. Visits and communication between Nursery School and Kindergarten children}

With regards to visits and communication between children of the Nursery School and the Kindergarten it was established that no statistically significant correlation occurs between group $\mathrm{A}\left(\mathrm{x}^{2}=3.223, \mathrm{df}=3\right.$ and $\left.\mathrm{p}=0.358\right)$ and group $\mathrm{B}\left(\mathrm{x}^{2}=8.762, \mathrm{df}=4\right.$ and $\left.\mathrm{p}=0.067\right)$ Kindergarten Educators and Nursery School Teachers. The aforementioned results are confirmed with the chi square measurement.

\section{b. Visits and communication between different Nursery Schools' children who shall be admitted into the same Kindergarten}

Regarding the inquiry whether the sample educationalists bring into contact and communication children of different Nurseries, who are to be enrolled into the same Kindergarten, it was established that in a total of N:409 educationalists, the majority (N:359) do not implement this specific practice. From the measurement with chi square method it became clear that a statistically significant correlation does occur regarding group $B(x 2=21.928, d f=4$ and $p=0.000)$, unlike group $A(x 2=0.571, d f=2$ and $p=0.752)$. As 
it is demonstrated on Table 2, group B Nursery School Teachers are neutral on a percentage reaching up to $45,6 \%$, while the respective percentage is $41,0 \%$ among the Kindergarten Educators. About one fifth of the Nursery School Teachers (18,1\%) would evaluate the specific practice as being "insignificant", while for the Educators the percentage is lower $(7,2 \%)$, who, to a $10,2 \%$ consider such a practice as being "highly significant". Respectively, the amount regarding the Nursery School Teachers is only $2,1 \%$.

Table 2: Quantitative of total results regarding practice:

"Visits and communication between different Nurseries' children who shall be admitted into the same Kindergarten"

\begin{tabular}{|c|c|c|c|c|}
\hline \multicolumn{5}{|c|}{ Crosstabulation } \\
\hline & & \multicolumn{2}{|c|}{ Group } & \multirow{2}{*}{ Total } \\
\hline & & Kindergarten Educators & Nursery School Teachers & \\
\hline \multirow{6}{*}{ Yes } & \multirow{2}{*}{$\begin{array}{l}\text { Neither significant } \\
\text { nor insignificant }\end{array}$} & 3 & 3 & 6 \\
\hline & & $12,0 \%$ & $12,5 \%$ & $12,2 \%$ \\
\hline & \multirow{2}{*}{ Significant } & 9 & 11 & 20 \\
\hline & & $36,0 \%$ & $45,8 \%$ & $40,8 \%$ \\
\hline & \multirow{2}{*}{ Highly significant } & 13 & 10 & 23 \\
\hline & & $52,0 \%$ & $41,7 \%$ & $46,9 \%$ \\
\hline \multirow{2}{*}{\multicolumn{2}{|c|}{ Total }} & 25 & 24 & 49 \\
\hline & & $100,0 \%$ & $100,0 \%$ & $100,0 \%$ \\
\hline \multirow{10}{*}{ No } & \multirow{2}{*}{ Insignificant } & 12 & 35 & 47 \\
\hline & & $7,2 \%$ & $18,1 \%$ & $13,1 \%$ \\
\hline & \multirow{2}{*}{ Slightly significant } & 31 & 22 & 53 \\
\hline & & $18,7 \%$ & $11,4 \%$ & $14,8 \%$ \\
\hline & \multirow{2}{*}{$\begin{array}{l}\text { Neither significant } \\
\text { nor insignificant }\end{array}$} & 68 & 88 & 156 \\
\hline & & $41,0 \%$ & $45,6 \%$ & $43,5 \%$ \\
\hline & \multirow{2}{*}{ Significant } & 38 & 44 & 82 \\
\hline & & $22,9 \%$ & $22,8 \%$ & $22,8 \%$ \\
\hline & \multirow{2}{*}{ Highly significant } & 17 & 4 & 21 \\
\hline & & $10,2 \%$ & $2,1 \%$ & $5,8 \%$ \\
\hline \multirow{2}{*}{\multicolumn{2}{|c|}{ Total }} & 166 & 193 & 359 \\
\hline & & $100,0 \%$ & $100,0 \%$ & $100,0 \%$ \\
\hline
\end{tabular}

The following two practices, enhancement of developing friendly relationships among the same division's children who shall be admitted into the same Kindergarten as well as enhancement of developing friendly relationships among different divisions' children who shall be admitted into the same Kindergarten, are addressed towards only Nursery School Teachers regarding their implementation, concern, however, both, the Kindergarten Educators and the Nursery School Teachers regarding their assessing. 


\section{c. Enhancement of developing friendly relationships among the same division's children who shall be admitted into the same Kindergarten}

Of a total N:217 Nursery School Teachers, 149 do implement the enhancement of friendly relationships' development among the children who attend the same division and shall be enrolled in the same Kindergarten. Subsequently, this practice went through an assessment not only by the Nursery School Teachers but also by the Kindergarten Educators; it was established that a statistically significant correlation occurs between the two variables $(\mathrm{x} 2=54.412, \mathrm{df}=4$ and $\mathrm{p}=0.000)$.

Table 3: Quantitative of total results regarding practice:

"Enhancement of developing friendly relationships among the same division's children who shall be admitted into the same Kindergarten"

\begin{tabular}{|c|c|c|c|c|}
\hline \multicolumn{5}{|c|}{ Crosstabulation } \\
\hline & & \multicolumn{2}{|c|}{ Group } & \multirow[t]{2}{*}{ Total } \\
\hline & & Kindergarten Educators & Nursery School Teachers & \\
\hline \multirow{6}{*}{ Yes } & \multirow{2}{*}{$\begin{array}{l}\text { Neither significant } \\
\text { nor insignificant }\end{array}$} & & 20 & 20 \\
\hline & & & $13,4 \%$ & $13,4 \%$ \\
\hline & \multirow{2}{*}{ Significant } & & 83 & 83 \\
\hline & & & $55,7 \%$ & $55,7 \%$ \\
\hline & \multirow{2}{*}{ Highly significant } & & 46 & 46 \\
\hline & & & $30,9 \%$ & $30,9 \%$ \\
\hline \multirow{2}{*}{\multicolumn{2}{|c|}{ Total }} & & 149 & 149 \\
\hline & & $100,0 \%$ & $100,0 \%$ & $100,0 \%$ \\
\hline \multirow{10}{*}{ No } & \multirow{2}{*}{ Insignificant } & 5 & 16 & 21 \\
\hline & & $2,6 \%$ & $23,5 \%$ & $8,0 \%$ \\
\hline & \multirow{2}{*}{ Slightly significant } & 14 & 8 & 22 \\
\hline & & $7,3 \%$ & $11,8 \%$ & $8,4 \%$ \\
\hline & \multirow{2}{*}{$\begin{array}{l}\text { Neither significant } \\
\text { nor insignificant }\end{array}$} & 47 & 30 & 77 \\
\hline & & $24,4 \%$ & $44,1 \%$ & $29,5 \%$ \\
\hline & \multirow{2}{*}{ Significant } & 81 & 8 & 89 \\
\hline & & $42,0 \%$ & $11,8 \%$ & $34,1 \%$ \\
\hline & \multirow{2}{*}{ Highly significant } & 46 & 6 & 52 \\
\hline & & $23,8 \%$ & $8,8 \%$ & $19,9 \%$ \\
\hline \multirow{2}{*}{\multicolumn{2}{|c|}{ Total }} & 193 & 68 & 261 \\
\hline & & $100,0 \%$ & $100,0 \%$ & $100,0 \%$ \\
\hline
\end{tabular}

More particularly, the majority of group B Nursery School Teachers $(44,1 \%)$ describes enhancement of friendly relationships among children of the same division as being "neither significant nor insignificant", while the highest amount of Kindergarten Educators (42,0\%) take it as "significant". Respectively, the percentages are $24,4 \%$ for Educators regarding "neither significant nor insignificant" and 11,8\% for Nursery School Teachers on the "significant" category. It is, additionally recorded that more than $20 \%$ of Nursery School Teachers (23,5\%) considers it as "insignificant" to a respective 2,6\% among the Educators, whereas $23,8 \%$ of the Educators would describe it as "highly 
significant". The respective percentage in Nursery School Teachers' case is $8,8 \%$ (Table 3). The aforementioned results are confirmed with the chi square measurement.

\section{d. Enhancement of developing friendly relationships among different divisions' children who shall be admitted into the same Kindergarten}

Regarding the inquiry about the enhancement of developing amicable relationships among different divisions' children who shall be enrolled into the same Kindergarten, it was found that 119 of the Nursery School Teachers implement the specific practice. Also, from the measurement with the use of chi square method a statistically significant difference occurs between both group $B$ variables $(x 2=60.126, \mathrm{df}=4$ and $\mathrm{p}=0.000)$.

More particularly, as shown in Table 4, a 49,0\% of Nursery School Teachers seem to be of neutral disposition in comparison to Kindergarten Educators who, by a percentage reaching $40,9 \%$ deem the specific practice as being a "significant" one. The respective percentages are $24,4 \%$ for Educators regarding "neither significant nor insignificant" categorization and 19,4\% for Nursery School Teachers on the "significant" categorization. Furthermore, another $19,4 \%$ of the sample's Nursery School Teachers considers this practice as being "insignificant", while lower is this categorization among Kindergarten Educators (3,1\%) who take it as "highly significant" on a percentage up to $21,8 \%$ whereas only one Nursery School Teacher is of positive disposition.

Table 4: Quantitative of total results regarding practice:

"Enhancement of developing friendly relationships among different divisions' children who shall be admitted into the same Kindergarten"

\begin{tabular}{|c|c|c|c|c|}
\hline \multicolumn{5}{|c|}{ Crosstabulation } \\
\hline & & \multicolumn{2}{|c|}{ Group } & \multirow[t]{2}{*}{ Total } \\
\hline & & Kindergarten Educators & Nursery School Teachers & \\
\hline \multirow{6}{*}{ Yes } & \multirow{2}{*}{$\begin{array}{l}\text { Neither significant } \\
\text { nor insignificant }\end{array}$} & & 5 & 5 \\
\hline & & & $4,2 \%$ & $4,2 \%$ \\
\hline & \multirow{2}{*}{ Significant } & & 75 & 75 \\
\hline & & & $63,0 \%$ & $63,0 \%$ \\
\hline & \multirow{2}{*}{ Highly significant } & & 39 & 39 \\
\hline & & & $32,8 \%$ & $32,8 \%$ \\
\hline \multirow{2}{*}{\multicolumn{2}{|c|}{ Total }} & & 119 & 119 \\
\hline & & $100,0 \%$ & $100,0 \%$ & $100,0 \%$ \\
\hline \multirow{10}{*}{ No } & \multirow{2}{*}{ Insignificant } & 6 & 19 & 25 \\
\hline & & $3,1 \%$ & $19,4 \%$ & $8,6 \%$ \\
\hline & \multirow{2}{*}{ Slightly significant } & 19 & 11 & 30 \\
\hline & & $9,8 \%$ & $11,2 \%$ & $10,3 \%$ \\
\hline & \multirow{2}{*}{$\begin{array}{l}\text { Neither significant } \\
\text { nor insignificant }\end{array}$} & 47 & 48 & 95 \\
\hline & & $24,4 \%$ & $49,0 \%$ & $32,6 \%$ \\
\hline & \multirow{2}{*}{ Significant } & 79 & 19 & 98 \\
\hline & & $40,9 \%$ & $19,4 \%$ & $33,7 \%$ \\
\hline & \multirow{2}{*}{ Highly significant } & 42 & 1 & 43 \\
\hline & & $21,8 \%$ & $1,0 \%$ & $14,8 \%$ \\
\hline \multirow{2}{*}{\multicolumn{2}{|c|}{ Total }} & 193 & 98 & 291 \\
\hline & & $100,0 \%$ & $100,0 \%$ & $100,0 \%$ \\
\hline
\end{tabular}




\section{e. Encouragement of children to freely create new friendships}

With regards to encouraging children to freely create new friendships it was established that no statistically significant correlation occurs between group A Kindergarten Educators and Nursery School Teachers $\left(\mathrm{x}^{2}=9.017, \mathrm{df}=4\right.$ and $\left.\mathrm{p}=0.061\right)$ and those of group $B\left(x^{2}=6.612, d f=4\right.$ and $\left.p=0.158\right)$. The aforementioned results are confirmed with the chi square measurement.

\section{f. Participation of Nursery School and Kindergarten children into common activities- events}

As shown in Table 5 the majority of educationalists (N:264) do not take part into commonly held activities-events between the Nursery and the Kindergarten. A statistically significant correlation was established only among group B Educators and Nursery School Teachers $\left(x^{2}=9.730, d f=4\right.$ and $\left.p=0.045\right)$, but not among the educationalists of group $\mathrm{A}\left(\mathrm{x}^{2}=3.078, \mathrm{df}=4\right.$ and $\left.\mathrm{p}=0.545\right)$.

More specifically, 38,9\% of Kindergarten Educators would evaluate this practice as a "significant" one, while the respective percentage regarding Nursery School Teachers is $43,6 \%$. About one fifth of Kindergarten Educators (18,5\%) describes it as "highly significant" as opposed to Nursery School Teachers $(8,3 \%)$ who by a percentage of $10,9 \%$ would see it as being "insignificant". Respectively, the percentage for Kindergarten Educators is 3,1\%. The aforementioned results are confirmed with the chi square measurement.

Table 5: Quantitative of total results regarding practice:

"Participation of Nursery and Kindergarten children into common activities-events"

\begin{tabular}{|c|c|c|c|c|}
\hline \multicolumn{5}{|c|}{ Crosstabulation } \\
\hline & & \multicolumn{2}{|c|}{ Group } & \multirow[t]{2}{*}{ Total } \\
\hline & & Kindergarten Educators & Nursery School Teachers & \\
\hline \multirow{10}{*}{ Yes } & \multirow{2}{*}{ Insignificant } & 1 & 0 & 1 \\
\hline & & $1,2 \%$ & $0,0 \%$ & $0,7 \%$ \\
\hline & \multirow{2}{*}{ Slightly significant } & 3 & 0 & 3 \\
\hline & & $3,6 \%$ & $0,0 \%$ & $2,1 \%$ \\
\hline & \multirow{2}{*}{$\begin{array}{l}\text { Neither significant } \\
\text { nor insignificant }\end{array}$} & 4 & 3 & 7 \\
\hline & & $4,8 \%$ & $4,9 \%$ & $4,9 \%$ \\
\hline & \multirow{2}{*}{ Significant } & 39 & 29 & 68 \\
\hline & & $47,0 \%$ & $47,5 \%$ & $47,2 \%$ \\
\hline & \multirow{2}{*}{ Highly significant } & 36 & 29 & 65 \\
\hline & & $43,4 \%$ & $47,5 \%$ & $45,1 \%$ \\
\hline \multirow{2}{*}{\multicolumn{2}{|c|}{ Total }} & 83 & 61 & 144 \\
\hline & & $100,0 \%$ & $100,0 \%$ & $100,0 \%$ \\
\hline \multirow{5}{*}{ No } & \multirow{2}{*}{ Insignificant } & 5 & 17 & 22 \\
\hline & & $4,6 \%$ & $10,9 \%$ & $8,3 \%$ \\
\hline & \multirow{2}{*}{ Slightly significant } & 12 & 19 & 31 \\
\hline & & $11,1 \%$ & $12,2 \%$ & $11,7 \%$ \\
\hline & Neither significant & 29 & 53 & 82 \\
\hline
\end{tabular}



OF APPROPRIATE DEVELOPMENTAL PRACTICES DURING EARLY CHILDHOOD

\begin{tabular}{|l|l|c|c|c|}
\hline \hline \multirow{3}{*}{} & nor insignificant & $26,9 \%$ & $34,0 \%$ & $31,1 \%$ \\
\cline { 2 - 5 } & \multirow{2}{*}{ Significant } & 42 & 54 & 96 \\
\cline { 2 - 5 } & \multirow{2}{*}{ Highly significant } & $38,9 \%$ & $34,6 \%$ & $36,4 \%$ \\
\cline { 2 - 5 } & 20 & 13 & 33 \\
\hline \multirow{2}{*}{ Total } & $18,5 \%$ & $8,3 \%$ & $12,5 \%$ \\
\cline { 2 - 5 } & 108 & 156 & 264 \\
\hline
\end{tabular}

\section{Interpretation of results and Discussion}

From the exploratory findings of the current study it seems that there is a convergence among the views of participating Greek Nursery School Teachers and Kindergarten Educators not only regarding the transition practices they implement on the purpose of enhancing inter-personal relationship among early childhood children, but also towards the evaluation of the specific strategies. Given that early childhood Instructors consider child inter-personal relationships as being of major importance to a well-tempered transition, the vast majority of educationalists, positively utilize and evaluate encouraging child to freely make new friends along with enhancing the development of friendly relationships among pupils of the same division who are to be enrolled at the same Kindergarten.

Established by research as well as by numerous studies, friends do hold a vital role towards assuring a successful transition (Bernd \& Perry, 1986; Bulkeley \& Fabian, 2006; Einarsdóttir, 2002; Fabian, 2000; Griebel \& Niesel, 1999; Ladd \& Price, 1987; Ladd, 1990; Ladd, 2009; Peters, 2000; Schwarz, 1972; Margetts, 2002; O'Hara, 2000). According to Sakellariou (2005) the way most effective on assisting child build friendships is using multiple methods on teaching social skills (behavior shaping, role model, trainingexercise).

As an interesting finding, non-utilization of practices is recorded; practices such as common activities-events (visiting, along with the Nursery pupils' companion, the Kindergarten facility, inviting Kindergarten pupils to visit the Nursery but also the Kindergarten Educator to talk children about the new environment) as well as visits and communication among children of different Nurseries who shall be admitted into the same Kindergarten. Although such practices are positively evaluated by the majority of pre-school Educationalists, but a few of them actually implement any of those during the school year. Consequently, one could in fact advocate that there is not any interaction between Nursery School Teachers and Kindergarten Educators whatsoever. Such deviation could be attributed to factors like inadequate retraining on programs and transition techniques, workspace, lack of support by the Principal and colleagues, low salary, inexistence of free time, deprivation of knowledge in terms of strategies and practices as well as the overall educational policy (Sakellariou, Anagnostopoulou, Strati \& Tzima, 2016). 
The quality of a program that is orientated towards a smooth transition into compulsory education depends highly on the way Instructors realize the role themselves have to take on (Sakellariou, Anagnostopoulou, Strati, 2015) but also on the developmentally appropriate practices they choose to utilize as being the main representative of "optimal practices" (Hedge \& Cassidy, 2009; Liu, 2007; McMullen \& Alat, 2002; McMullen et al., 2005; Sakellariou \& Rentzou, 2012; Suk Lee, Baik, \& Charlesworth, 2006). It is therefore of dire need that preschool education workers are retrained along with attending seminaries on issues that regard transition into compulsory education, which shall set the sparkle for a more extensive debate, views exchange, experimentation and investigation.

The procedure of a well-tempered transition ought to be incorporated into the educational process via: a) pedagogy which promotes curiosity, incentives, social, emotional development of child, b) programs that are supportive to children and families as they are making their way through Nursery into Kindergarten and c) educational policy which by law promotes regulations, actions as well as legislative ordinances that support and affect preschool learning structures (Kagan, Karnati, Friedlander, \& Tarrant, 2010) into implementing all practices and strategies good for promoting a smooth transition of children into compulsory education. Instructors no less all bodies in charge on forming the educational policy, should fully comprehend the impact posed by the changes children and families experience during the transition into compulsory education and they should offer a preschool learning environment that is rich in stimuli, child and family-friendly so that children become capable of confidently confront all unprecedented experiences, new challenges and changes, as their pave their way from one educational context to the next.

\section{References}

American Academy of Child and Adolescent Psychiatry (2002): Starting School.

Australian Government Department of Education, Employment and Workplace Relations for the Council of Australian Governments. (2009). Belonging, Being and Becoming. The Early Years Learning Framework for Australia.

Barblett, L., Barratt-Pugh, C.H., Kilgallon, P.A., \& Maloney, C. (2011). Transition from long day care to kindergarten: Continuity or not? Australasian Journal of Early Childhood, 36(2), 42-49.

Bernd, T.J., \& Perry, T.B. (1986). Children's Perception of Friendships as supportive Relationships. Developmental Psychology, 22, 540-648.

Bogard, K., \& Takanishi, R. (2005). PreK-3: An aligned and coordinated approach to education for children 3 to 8 years old. SRCD Social Policy Report, 29(3), 3-23.

Bohan-Baker, M. \& Little, P.M.D. (2004). The transition to kindergarten: A review of current research and promising practices to involve families. Cambridge, MA: Harvard Family Research Project. 
Bredekamp, S. (1987). Developmentally appropriate practice in early childhood programs servicing children from birth through age 8. Washington: NAEYC.

Brock, A. Dodds, S., Jarvis, P., \& Olusoga, Y. (2016). Pedagogy of play in pre-school and school education. Athens: Pedio.

Bronfenbrenner, U. (1986). Ecology of the family as a context of human development: Research perspectives. Developmental Psychology 22(6), 723-742.

Broström, S. (2002). Communication and continuity in the transition from Kindergarten to School. In H. Fabian \& A. W. Dunlop (Eds.), Transitions in the Early Years: Debating continuity and progression for young children in early education (pp. 52-63). London and New York: Routledge Falmer.

Broström, S. (2005). Transition problems and play as transitory activity. Australian Journal of Early Childhood, 30(3), 17-25.

Bulkeley, J., \& Fabian, D. (2006). Well-being and belonging during early educational transitions. International Journal of Transitions in Childhood, 2, 18-31.

Cappelloni, N.L. (2011). Kindergarten Teachers' Perceptions of Kindergarten Readiness.

Dockett S., \& Perry, B. (2001). Starting school: Effective transitions. Early Childhood Research and Practice, 3, 1-19.

Dockett, S., \& Perry, B. (1999). Starting school: What do the children say? Early Child Development and Care, 159, 107-119.

Dockett, S., \& Perry, B. (2003). The Transition to School: What's important? Educational Leadership, 60(7), 30-34.

Early, D.M., Pianta, R.C., Taylor, L.C., \& Cox, M.J. (2001). Transition Practices: Findings from a National Survey of Kindergarten Teachers. Early Childhood Education Journal, 28(3), 199-206.

Einarsdóttir, J. (2002). Children's Accounts of the Transition from Preschool to Elementary School. Barn, 4, 49-72.

Fabian, H. (2000, August - September). A Seamless Transition? Paper presented on the 10th European Conference on Quality in Early Childhood Education (EECERA),London.

Fowler, S.A. (1982). Transition from preschool to kindergarten for children with special needs. In K.E. Allen \& E.M. Goetz (Eds.), Early Childhood education: Special problems, special solutions (pp. 229-224). Rockville, MD: Aspen.

Garrett, D. (2001). The transition to school. Factors which assist or inhibit children in their transition to school. Unpublished Masters thesis. Institute of Early Childhood Macquarie University.

Germanos, D. (2002). Walls of knowledge, school space and education. Athens: Gutenberg.

Germanos, D. (2004). Space and educational processes. Pedagogical quality of space. Athens: Gutenberg.

Gill, S., Winters, D., \& Friedman, D.S. (2006). Educators' views of pre-kindergarten and kindergarten readiness and transition practices. Contemporary Issues in Early Childhood, 7,(3), 213-227. 
Griebel, W., \& Niesel, R. (1999, September). From Kindergarten to school: A transition for the family. Paper presented at 9th European Conference on Quality in Early Childhood Education (EECERA), Helsinki.

Griebel, W., \& Niesel, R. (2002). Co-constructing transition into Kindergarten and school by children, parents and teachers. In H. Fabian \& A.W. Dunlop (Eds.), Transitions in the Early Years: Debating continuity and progression for young children in early education (pp. 64-75). London and New York: Routledge Falmer.

Hains, A.H., Fowler, S.A., \& Chandler, L.K. (1988). Planning school transition: Family and professional collaboration. Journal of the Division for Early Childhood, 12(2), 108115.

Hedge, A.V., \& Cassidy, D.J. (2009). Kindergarten teachers' perspectives on developmentally appropriate practices (DAP): A study conducted in Mumbai (India). Journal of Research in Childhood Education, 23(3), 367-381.

Howes, C. (1988). Peer interaction of young children. Monographs of the Society for Research in Child Development 53 (2. Serial No. 217). In K. Maxwell \& C. Eller,(1994, September) Children's Transition to Kindergarten, Young Children.

Kagan, S.L., \& Neuman. M.J. (1998). Lessons from three decades of transition research. The Elementary School Journal, 98 (4), 365-379.

Kagan, S.L., Karnati, R., Friedlander, J., \& Tarrant, K. (2010). A Compendium of Transition Initiatives in the Early Years. A Resource Guide to Alignment and Continuity Efforts in the United States and other Countries. National Center for Children and Families.

Kitsaras, G. (1988). Introduction to Preschool Pedagogy. Athens.

Kraft-Sayre, M.E., \& Pianta, R.C. (2000). Enhancing the transition to kindergarten. Charlottesville: University of Virginia, National Center for Early Development \& Learning.

La Paro, K.M., Kraft-Sayre, M. \& Pianta, R.C. (2003) Preschool to kindergarten transition activities: Involvement and satisfaction of families and teachers. Journal of Research in Childhood Education, 17(2), 147-158.

Ladd, G.W. \& Price, J.M. (1987). Predicting children's social and school adjustment following the transition from pre-school to kindergarten. Child Development, 58, 1168-1189.

Ladd, G.W. (1990). Having Friends, Keeping Friends, Making Friends, and being Liked by Peers, in the Classroom: Predictors of Children's Early School Adjustment? Child Development, 61, 1081-1100.

Ladd, GW. (2009). School readiness: Preparing children for the transition from preschool to grade school. Comments on Love and Raikes, Zill and Resnick, and Early. In R.E. Tremblay, M. Boivin, \& RDeV. Peters (Eds.), Encyclopedia on Early Childhood Development [online].

Lee, Y., Baik, J., \& Charlesworth, R. (2006). Differential effects of kindergarten teachers' beliefs about developmentally appropriate practice on their use of scaffolding following inservice training. Teaching and Teacher Education, 22, 935-945. 
Lenga, R., \& Ogden, V. (2000). Lost in Transit: Attainment Deficit in Pupil Transition from Key Stage 2 to Key Stage 3. London: Institute of Education.

Liu, H.C. (2007). Developmentally appropriate beliefs and practices of public and private kindergarten teachers in the United States and Taiwan. PhD Dissertation Thesis, Texas, TX: University of Texas.

Lo-Casale Crouch, J., Mashburn, A.J., Downer, J.T., \& Pianta, R.C. (2008). Prekindergarten teachers' use of transition practices and children's adjustment to kindergarten. Early Childhood Research Quarterly, 23, 124-139.

Margetts, K. (1999, July). Transition to School: Looking Forward. (Selected papers from the AECA National Conference Darwin).

Margetts, K. (2002). Planning transition programmes. In H. Fabian \& W.A. Dunlop (Eds.), Transitions in the Early Years: Debating continuity and progression for young children in early education (pp. 111-122). London and New York: Routledge Falmer.

Margetts, K. (2007). Understanding and supporting children: shaping transition practices. In A.W. Dunlop \& H. Fabian (Eds.), Informing transitions in the early years (pp. 107-119). London: Open University Press.

McMullen, M.B., \& Alat, K. (2002). Education matters in the nurturing of the beliefs of preschool caregivers and teachers. Early Childhood Research E Practice, 4(2).

McMullen, M.B., Elicker, J., Wang, J., Erdiller, Z., Lee, S.M., Lin, C.H., \& Sun, P.Y. (2005). Comparing beliefs about appropriate practice among early childhood education and care professionals from the U.S., China, Taiwan, Korea and Turkey. Early Childhood Research Quarterly, 20, 451-464.

Meyer, L.H., \& Bevan-Brown, J. (2000). Supporting social relationships: Partnerships and friendships. In D. Fraser, R. Moltzen, \& K. Ryba (Eds.), Learners with special needs in Aotearoa New Zealand (2nd Ed.) (pp147-180). Palmerston North: Dunmore Press.

Michalopoulou, Aik., \& Grantza, A. (2014). The Design, Realisation, and Evaluation of an Educational Programme: Promoting Play in Kindergarten, The International Journal of Early Childhood Learning, 20(4), 11-17.

Michalopoulou, K. (2007). Explanatory Speaking in Kindergarten: Designing and implementation of a program. In A. Vellopoulou (ed.), Proceedings of the $6^{\text {th }}$ PanHellenic Conference "Language as a means and learning object within pre-school and school ages (pp. 233-237). O.M.E.P. (Organisation Mondiale pour l'Éducation Préscolaire) and Department of Early Childhood Education and Training Sciences.

Ntoliopoulou, E. (2006). Contemporary trends in Preschool Education. Athens: Typothito, G. Dardanos.

O'Hara, M. (2000). Teaching 3-8 meeting the standards for initial teaching and induction. London: Continuum.

Pantazis, S. (2004). Pedagogy and Play-Object into the Kindergarten's domain. Athens: Gutenberg.

Patton, C.H., \& Wang, J. (2012). Ready for Success: Creating Collaborative and Thoughtful Transitions into Kindergarten. Harvard Family Research Project. 
Pellegrini, A.D., \& Blatchford, P. (2000). The child at school: interactions with peers and teachers. London: Arnold.

Peters, S. (2000, August 29 - September 1). Multiple perspectives on continuity in early learning and the transition to school. Paper presented at 10th European Early Childhood Education Research Association Conference: "Complexity, diversity and multiple perspectives in early childhood", University of London, London.

Pianta, R.C., Rimm-Kaufman, S.E., \& Cox, M. (1999). Introduction: An ecological approach to kindergarten transition. In R.C. Pianta \& M.J. Cox (Eds.), The transition to kindergarten (pp. 3-12). Baltimore, MD: Paul H. Brookes.

Piotrkowski, C.S., Botsko, M., \& Matthews, E. (2000). Parents' and teachers' beliefs about children's school readiness in a high-need community. Early Childhood Research Quarterly, 15(4), 537-558.

Pollard, A. (1996) The Social World of Children's Learning. London: Cassell.

Repetto, J.B., \& Correa, V.I. (1996). Expanding views on transition. Exceptional Children, 62,(6), 551-63.

Rimm-Kaufman S.E., \& Pianta, R.C. (2000). An ecological perspective on the transition to kindergarten: A theoretical framework to guide empirical research. Journal of Applied Developmental Psychology, 21(5), 491-511.

Rimm-Kaufman, S.E., \& Pianta, R.C. (1999). Patterns of family-school contact in preschool and kindergarten. School Psychology Review, 28(3), 426-438.

Rous, B., Hallam, R., McCormick, K., \& Cox, M. (2010). Practices that support the transition to public preschool programs: Results from a National Survey. Early Childhood Research Quarterly, 25, 17-32.

Sakellariou, M. (2005). Children's friendships in Kindergarten. An approach through research findings. In S. Pantazis \& M. Sakellariou (ed.) Pre-school Pedagogy (pp. 325353). Athens: Atrapos.

Sakellariou, M., \& Rentzou, K. (2012). Comparing beliefs about and practices of developmental appropriate practices among Greek and Cypriot pre-service kindergarten teachers. Early Child Development and Care, 128(10), 1309-1324.

Sakellariou, M., Anagnostopoulou, R. \& Strati, P. (2015, May). Factors affecting children's well-tempered transition from Family to Nursery and Kindergarten. Proceedings of the $2^{\text {nd }}$ International Early Childhood Pedagogy Symposium "Transformative Pedagogy and Learning during Childhood". Ioannina: University of Ioannina.

Sakellariou, M., Anagnostopoulou, R., Strati, P. \& Tzimas, P. (2016, April). Practices appropriate for a successful transition outcome from family to pre-school environment. In 3rd Early Childhood Pedagogy Symposium: "Contemporary Trends in Curriculum Development and Teaching". Nicosia.

Schwarz, J.C. (1972). Effects of peer familiarity on the behaviour of pre-schoolers in a novel situation, Journal of Personality and Social Psychology, 24, 276-284

Sidiropoulou. Tr., Dimitriadi, S. \& Ralli, A. (2011). The young child's transition through different educational environments. Pedagogikos Logos, 1, 63-83. 
Vairinou, K. (2008). Designing and assessing an educational program towards the enhancement of social acceptance and collaborative learning In S. Avgitidou (ed.), Collaborative Learning in Preschool Education: Research and Implementation (pp. 99120). Athens: Gutenberg. will be applied to their work. Under the terms of this license, no permission is required from the author(s) or publisher for members of the community to copy, distribute, transmit or adapt the article content, providing a proper, prominent and unambiguous attribution to the authors in a manner that makes clear that the materials are being reused under permission of a Creative Commons License. Views, opinions and conclusions expressed in this research article are views, opinions and conclusions of the author(s). Open Access Publishing Group and European Journal of Social Sciences Studies shall not be responsible or answerable for any loss, damage or liability caused in relation to/arising out of conflicts of interest, copyright violations and inappropriate or inaccurate use of any kind content related or integrated into the research work. All the published works are meeting the Open Access Publishing requirements and can be freely accessed, shared, modified, distributed and used in educational, commercial and non-commercial purposes under a Creative Commons Attribution 4.0 International License (CC BY 4.0). 